\title{
АЛГОРИТМ ВИКОРИСТАННЯ КРИТЕРІЮ МАКНАМАРА ДЛЯ СТАТИСТИЧНОЇ ОБРОБКИ ПЕДАГОГГЧНИХ ВИМІРЮВАНЬ
}

\begin{abstract}
Пісоцька М. Е.
доктор педагогічних наук, доцент, професор кафедри освітології та інноваційної педагогіки, Харківський національний педагогічний

університет імені Г. С. Сковороди, м. Харків, Україна

\section{Олійник Т. О.}

кандидат педагогічних наук, доцент, доцент кафедри інформаційних технологій, Харківський національний педагогічний університет імені Г. С. Сковороди, м. Харків, Україна
\end{abstract}

У статті схарактеризовано особливості застосування непараметричних методів математичної статистики, наданий алгоритм використання критерію Макнамара для перевірки на достовірність статистичних гіпотез як припущень щзодо результатів педагогічних досліджень, констатовано умови застосування критерію, наведено приклад математичної обробки результатів педагогічних вимірювань за названим критерієм.

Ключові слова: математична статистика, непараметричні методи, критерій Макнамара, педагогічні дослідження.

The article describes the peculiarities of using nonparametric methods of mathematical statistics, provides an algorithm for using the McNamara criterion to test the reliability of statistical hypotheses as assumptions about the results of pedagogical research, states the conditions of application of the criterion, and gives an example of mathematical processing of pedagogical measurements.

Key words: mathematical statistics, nonparametric methods, McNamara criterion, pedagogical researches.

Критерій Макнамара належить до непараметричних методів статистичної обробки результатів педагогічних вимірювань. При використанні методів цієї групи не вимагається здійснення припущення про конкретний тип розподілу генеральних сукупностей, проведення розрахунків параметрів розподілу ймовірностей, а передбачається оперування лише з частотами повторень. Саме тому непараметричні методи $\epsilon$ простими щодо застосування математичного апарату та не потребуют богато часу. 
Критерій Макнамара придатний для математичної обробки результатів двох залежних вибірок (одні й ті ж самі об'єкти до та після педагогічного впливу) у випадках, коли педагогічні вимірювання здійснюють за шкалою найменувань, що має лише дві категорії (розподіл об'єктів за досліджуваною властивістю можливий лише на дві групи: подобається - не подобається; вище - нижче; краще - гірше; так ні тощо). Прийнято позначати одну з двох категорій через «0», а іншу «1». Отже, результати двократного вимірювання однієї і тієї ж властивості в одного й того ж самого об'єкта до та після педагогічного впливу можуть бути тільки чотирьох видів: $(0,0) ;(0,1) ;(1,1) ;(1,0)$. У підрахунках за критерієм беруть участь тільки об’єкти у стані досліджуваної властивості яких відбулися певні відмінності. Прийнято позначати через b кількість об'єктів, що отримали $(0,1)$, а через с кількість об'єктів, що отримали $(1,0)$. Якщо в результаті експерименту отримано дані згідно яким $b=c$, критерій Макнамара використовувати неможна.

Відправним моментом для застосування критерію є формулювання нульової та альтернативної гіпотез, які у загальному вигляді мають такий зміст: $\mathrm{H}_{0}$ : Стан досліджуваної властивості не $є$ відмінним у двох залежних вибірках. $\mathrm{H}_{1}$ : Стан досліджуваної властивості є істотно (статистично значущо) відмінним у двох залежних вибірках.

Для їхньої перевірки підраховують статистику критерію Т.

$$
\mathrm{T}=\left\{\begin{array}{c}
\frac{(b-c)^{2}}{b+c} \text { у випадку якщо } \mathrm{b}+\mathrm{c}>20 \\
\min (\mathrm{b}, \mathrm{c}) \text { у випадку якщо } \mathrm{b}+\mathrm{c} \leq 20
\end{array}\right.
$$

Рішення щодо прийняття або спростування певної гіпотези приймають відповідно наступного правила. Для $\mathrm{b}+\mathrm{c}>20$ порівнюють Т та $\mathrm{T}_{\text {кр }}$. Значення Ткр. залежить від обраного рівня значущості $\alpha$. При $\mathrm{T}_{\text {кр. }}=3,84$; при $\mathrm{T}_{\text {кр. }}=5,02 ;$ при $\mathrm{T}_{\text {кр. }}=6,63$. Якщо $\mathrm{T}>\mathrm{T}_{\text {кр. }}$, то гіпотеза $\mathrm{H}_{0}$ відхиляється на рівні значущості $\alpha$. Приймається альтернативна гіпотеза. Для $\mathrm{b}+\mathrm{c} \leq 20$ за таблицею критичних значень для біномінального розподілу за значенням $\mathrm{b}+\mathrm{c}$ та величині $\mathrm{T}$ знаходять величину Р. Якщо $\mathrm{P}<$, то гіпотеза $\mathrm{H}_{0}$ відхиляється на рівні значущості $\alpha$. Приймається альтернативна гіпотеза.

Наприклад, необхідно перевірити наявність істотних відмінностей в одержаних експериментальних даних при дослідженні впливу технології організації навчання учнів за допомогою випереджаючих за- 
вдань на рівень їхньої пізнавальної самостійності. На етапах констатуючого та контрольного експериментів здобувачі освіти виконували завдання для виявлення рівня сформованості пізнавальної самостійності. Були отримані наступні дані: в $\mathrm{E}_{1}$ класі навчається 36 учнів, із них у результаті експерименту залишилося на репродуктивному рівні 2 учня, на рівні вищому ніж репродуктивний - 12 учнів, підвищили свій рівень пізнавальної самостійності з репродуктивного на більш високий 18 учнів, знизили рівень до репродуктивного 4 учня.

При застосуванні критерію:

1, Обгрунтовуємо можливість його використання.

Оскільки вимірювання відбувалося за шкалою найменувань із двома категоріями: репродуктивний рівень - вище ніж репродуктивний рівень, вибірки залежні, $\mathrm{b} \neq \mathrm{c}$, можемо застосовувати критерій.

2. Формулюємо статистичні гіпотези.

$\mathrm{H}_{0}$ : Рівень пізнавальної самостійності учнів $\mathrm{E}_{1}$ класу до та після проведення формувального експерименту з перевірки ефективності технології організації навчання учнів за допомогою випереджаючих завдань істотно не змінився. $\mathrm{H}_{1}$ : Рівень пізнавальної самостійності учнів $\mathrm{E}_{1}$ класу до та після проведення формувального експерименту 3 перевірки ефективності технології організації навчання учнів за допомогою випереджаючих завдань істотно (статистично значущо) змінився.

3. Проводимо математичні розрахунки.

Позначимо через «0» - кількість учнів, що проявили репродуктивний рівень пізнавальної самостійності, через «1» — кількість учнів, що проявили вищий ніж репродуктивний рівень пізнавальної самостійності. У нашому прикладі $b=18$ - кількість учнів, що отримали $(0,1), c=4-$ кількість учнів, що отримали $(1,0)$.

Оскільки $\mathrm{b}+\mathrm{c}=22$, a 22>20 статистику критерію Т підраховуємо за формулою:

$$
\mathrm{T}=\frac{(b-c)^{2}}{b+c}=\frac{(18-4)^{2}}{22}=\frac{196}{22}=8,91
$$

Обираємо рівень значущості $\alpha=0,05$ (для педагогічних вимірювань такий рівень значущості вважається достатнім). Оскільки для даного рівня значущості $\mathrm{T}_{\text {кр. }}=3,84$ порівнюємо $\mathrm{T}=8,91$ з $\mathrm{T}_{\text {кр. }}=3,848,91>3,84$, тобто $\mathrm{T}>\mathrm{T}_{\text {кр. }}, €$ підстави для відхилення гіпотези Н0 та прийняття гіпотези $\mathrm{H}_{1}$ на рівні значущості $\alpha=0,05$. 
4. Робимо висновок. Отже, рівень пізнавальної самостійності учнів E1 класу до та після проведення формувального експерименту з перевірки ефективності технології організації навчання учнів за допомогою випереджаючих завдань істотно (статистично значущо) змінився.

\section{Список використаних джерел:}

1. Вдовенко В. В. Математичні методи в психології : навчально-методичний посібник. Кіровоград : ПП Центр оперативної поліграфії «Авангард», 2017. $112 \mathrm{c}$.

2. Криворот Т. Г. Непараметричні методи математичної статистики для оцінки ефективності педагогічних нововведень. Педагогіка формування творчої особистості у вищій і загальноосвітній школах. 2013. Вип. 32 (85). C.288- 295. 